\title{
"We're Only Monsters": Punk Bodies and the Grotesque in 1970s Northern Ireland
}

\author{
Timothy A. Heron
}

\section{(2) OpenEdition \\ 1 Journals}

\section{Electronic version}

URL: http://journals.openedition.org/etudesirlandaises/5162

DOI: 10.4000/etudesirlandaises.5162

ISSN: 2259-8863

\section{Publisher}

Presses universitaires de Rennes

\section{Printed version}

Date of publication: 29 June 2017

Number of pages: 139-154

ISBN: 978-2-7535-5495-5

ISSN: 0183-973X

\section{Electronic reference}

Timothy A. Heron, " "We're Only Monsters": Punk Bodies and the Grotesque in 1970s Northern Ireland », Études irlandaises [Online], 42-1 | 2017, Online since 29 June 2019, connection on 07 September 2019. URL : http://journals.openedition.org/etudesirlandaises/5162 ; DOI : 10.4000/ etudesirlandaises.5162 


\title{
"We're Only Monsters": Punk Bodies and the Grotesque in 1970s Northern Ireland ${ }^{1}$
}

\author{
Timothy A. Heron \\ Université de Reims Champagne-Ardenne
}

Abstract

Throughout the late 1970s and early 1980s, at a time when cross-community contact was relatively uncommon in Northern Ireland, the punk subculture attracted both young Catholics and Protestants who temporarily set aside their political, religious and class differences. These young people signalled their participation in the subculture by adopting a dress style which, at the time, was considered shocking. Indeed, punk bodies were interpreted by observers and constructed by punks themselves in terms that evoked the grotesque, the abject and the monstrous. Such bodies were also a common feature in punk iconography and appeared in punk rock songs. In this paper I aim to show how Northern Irish punks, by displaying and celebrating these bodily characteristics in a society where they were generally used to identify and describe the "other" in a sectarian framework, threatened to disturb order and encouraged or at least enabled the transgression of gender and sectarian boundaries.

Keywords: punk, grotesque, body, Northern Ireland, popular culture.

\section{Résumé}

Tout au long des années 1970 et 1980, à une époque où les contacts entre les communautés étaient relativement limités en Irlande du Nord, la sous-culture punk attira à la fois des jeunes catholiques et protestants qui faisaient provisoirement abstraction de leurs différences politiques, religieuses et sociales. Ces jeunes gens signalaient leur appartenance à la culture punk en adoptant un style vestimentaire qui, à l'époque, paraissait choquant. De fait, les corps punks étaient perçus par ceux qui les observaient, et construits par les punks eux-mêmes, comme relevant du grotesque, de l'abject et du monstrueux. Ces corps apparaissaient fréquemment dans l'iconographie punk, ainsi que dans les chansons des groupes de punk rock. Dans cet article je montre que les punks nordirlandais, en exhibant et en célébrant ces caractéristiques corporelles dans une société où elles étaient généralement utilisées pour identifier et stigmatiser l'" autre " catholique ou protestant, menaçaient de perturber l'ordre public et encourageaient, ou du moins rendaient possible, le franchissement de barrières religieuses et genrées.

Mots clés: punk, grotesque, corps, Irlande du Nord, culture populaire.

1. This article was written thanks to the support of the SOFEIR research scholarship. 
"There was a nightmare coming to life, it was overpowering and disturbing. Something had been given permission to show itself, it was exploding out ${ }^{2}$." - Mary Harron

"Ballroom dancers would have run for their lives had they been at the Pound Hall in Townsend Street, Belfast, last night", reads an article on the front page of the Belfast Newsletter on Friday $13^{\text {th }}$ January $1978^{3}$. Visitors, it warns, "are liable to be spat upon - at least". This highlights an aspect of punk which is often forgotten or glossed over: its grotesque nature. Indeed, as a cultural phenomenon and as a mode of artistic and human expression, punk juxtaposed elements that were generally seen as mutually exclusive, developed an aesthetic which celebrated the monstrous, and encouraged performances and behaviours which were deemed abject, thus disturbing boundaries and provoking strong emotional responses ${ }^{4}$. Now that the codes and iconography of punk have been integrated into mainstream fashion, media and advertising, and at a time when punk's fortieth anniversary is being celebrated in London with the official support of the Mayor's Office and the British National Lottery, it is easy to forget how disturbing it really was. And yet it was this very quality that made punk - despite a relatively small base of participants - such an influential cultural force.

Punk is notoriously hard to define; it is a both a subculture ${ }^{5}$ and a complex cultural phenomenon which spanned several decades and several media - music, fashion, the visual arts, the alternative press, etc. Punk rock was an aggressive, fast and minimalist genre of popular music which partly arose as a reaction against contemporary popular music which was perceived as being too commercial and unexciting or too pretentious and removed from the fan. This dissonant style of music was associated with a discordant style of dress. Punk's colourful and eccentric haircuts, its angular lines and its rip-and-tear aesthetic defied high street $1970 \mathrm{~s}$ fashion, upset parents and drew daring young people to this "new teenage cult". As a subculture, it emerged in London in 1976 and soon made its way to Northern Ireland ${ }^{7}$. Although the violence of the Troubles and the climate of fear affected

2. Jon Savage, England's Dreaming: Anarchy, Sex Pistols, Punk Rock, and beyond, New York, St. Martin's Griffin, 2002, p. 241.

3. In Northern Ireland the main newspapers mostly ignored the punk phenomenon, as they had more urgent matters to cover. However, local editions of the British tabloids were published.

4. For a longer discussion of the grotesque, see below.

5. Use of the term "subculture" is controversial, but we use the concept as it is defined by Paul Hodkinson, who addresses much of the criticism that has been directed against it. According to his definition, a subculture must respond to four different criteria: identity, commitment, consistent distinctiveness and autonomy. See Paul Hodkinson, Goth: Identity, Style, and Subculture, Oxford, Berg, 2002, p. 29.

6. Nationwide, 12 November 1976, BBC One.

7. Punk spread to Northern Ireland much as it did to the cities and regions of Britain: through John Peel's late night radio BBC One programme, music papers - NME, Sounds, Melody Maker - sensationalist reports in tabloids, siblings or friends coming back from a visit in Britain, and, by the summer of 1977, through the appearance of punk rock and new wave bands on Top of the Pops on the BBC. 
music groups - the 1975 Miami Showband massacre ${ }^{8}$ discouraged many international rock bands from visiting Northern Ireland - a vibrant local scene emerged, with many young people starting bands such as the Undertones, Rudi, Stiff Little Fingers, the Outcasts, Ruefrex and scores of others. At a time when prolonged crosscommunity contact was relatively uncommon, despite the efforts led by government agencies and religious organisations to foster better community relations, punk attracted both young Catholics and Protestants who temporarily set aside their political, religious and class differences and met up in streets and record shops (Caroline Records, Good Vibrations) or one another's homes during the day, and at night crowded into the few spaces that allowed punk rock bands to play (bars such as the Harp, the Pound in Belfast or the Casbah in Derry, etc.). Throughout the late 1970s and early 1980s, punk provided these young people with the opportunity to secure a space in the margins where they could temporarily retreat from the conflict and create an "Alternative Ulster" in which cross-community coexistence, cooperation and camaraderie was possible. Elsewhere I have dealt with the emergence of a punk scene in Northern Ireland despite the lack of a proper infrastructure for rock music, thanks in part to punk's adoption of do it yourself practices, and I have discussed how, why and to what extent the punk subculture facilitated the transgression of sectarian, class and gender barriers'. In this paper I will articulate several related concepts - the grotesque, the abject and the monstrous - in order to argue that punk encouraged or at least enabled the questioning of gender and sectarian boundaries in a society where they were strictly codified. I will focus on punk bodies as well as on the representation of grotesque, monstrous bodies in punk songs.

\section{疄 Dress to Distress}

People generally encountered punk dress before hearing punk rock, not only because of limited airplay on radio stations, but because punks appeared in the streets before the first singles or albums were pressed: thus punk's initial shock was visual. Punk dress ${ }^{10}$ has a complex genealogy, but its most recognisable form

8. On 31 July 1975 three members of the popular Miami Showband were gunned down by the loyalist Ulster Volunteer Force on their way back to Dublin and the other two were injured in a sectarian attack. The incident shocked opinion north and south of the border.

9. See for instance Timothy Heron, "Alternative Ulster: Punk and the Construction of Everyday Life in 1970s Northern Ireland", Popular Culture Today. Imaginaires n 19, Presses universitaires de Reims, 2015 and "Parochial, not provincial? Punk outside the metropolis: the case of Northern Ireland", Four Nations History Network, 2015 [https://fournationshistory.wordpress.com/2015/12/07/833/].

10. For the purpose of this article, I rely on Joanne Eicher's definition of dress: "A system of nonverbal communication that enhances human being's interaction as they move in space and time. As a coded sensory system, dressing the body occurs when human beings modify their bodies visually or through other sensory measures by manipulating color, texture, scent, sounds, and taste or by supplementing their bodies with articles of clothing and accessories, and jewelry." Quoted in Monika Sklar, Punk Style, 2014, London, Bloomsbury, p. 8. 
emerged from the cross-pollination of entrepreneurs and designers Malcolm McLaren and Vivienne Westwood and an art school milieu nicknamed "the Bromley Contingent" which converged around the Sex Pistols and the couple's Sex/Seditionaries boutique on London's King's Road in $1976^{11}$. The dress style was picked up by the broadcast media and immediately associated with punk rock. A less art school, more street-orientated style emerged as young people across the isles drew inspiration from these images to construct their own punk dress in their own contexts. In 1970s UK and Ireland it was not difficult to stand out: cutting one's hair or getting one's trouser legs taken in were enough to single one out from the crowd. Cobley notes how the "muted tones" of punk dress in Wigan and other peripheral areas were enough to shock: in rural areas and towns unused to flamboyant self-expression, punks "did not have to work as hard to provoke onlookers" as their peers in London ${ }^{12}$. And yet punk dress in the north of Ireland was by no means subdued. Reading testimonies and perusing pictures of the era, it becomes clear that Northern Irish punk dress shared many of the characteristics of its London counterpart. Recourse to customised clothes or repurposed items may well have played a more important part than in major English cities - DIY (do-it-yourself) practice was particularly important in peripheral scenes - but many Northern Irish punks occasionally made the bus and ferry journey to London to stock up on clothes from Sex/Seditionaries and other boutiques. For an overview of Northern Irish punk dress, it is best to turn to the testimonies of participants themselves:

[We wore] safety pins, rips, chains, writing, badges; every punk cliché you could think of was used, [...], dyed spiky hair, blue suede buckled creepers, bondage gear, leathers, t-shirts, the whole shebang ${ }^{13}$.

Torn blazers, Dr. Marten boots and army trousers were in, along with granddad shirts and ripped black jumpers; out went parallel trousers and bell-bottom jeans, along with jet-wing-collar shirts and steel-capped Oxford brogues. [...] I used [razor] blades to hack through my hair in order to create that messed-up spiky ${ }^{14}$ look I had seen first on Brighton's

11. A similar scene emerged in the seaside resort of Bangor in Northern Ireland: the "Young Americans" were to Northern Ireland what the Bromley Contingent was to London. See book The Punk Trilogy (web) by Dee Wilson [www. thepunktrilogy.co.uk]..

12. Paul Cobley, "Leave the Capitol" in Roger Sabin (ed.) Punk rock, so what? the cultural legacy of punk, London, Routledge, 2009, p. 171.

13. Joe Donnelly in Sean O'Neill and Guy Trelford. It Makes You Want to Spit!: The Definitive Guide to Punk in Northern Ireland, 1977-1982, Dublin, Reekus, 2003, p. 79. The book contains numerous first-hand testimonies by participants of the Northern Irish 1970s punk scene.

14. Despite subsequent representations in popular culture, the famed "Mohican" haircut was only adopted by punks towards the end of the 1970s. 
streets and later in downtown Belfast. [...] My mother [...] even designed my own bondage trousers made from stolen pieces of manhole tape and the buckles of old schoolbags ${ }^{15}$.

Although they were a minority, women played a more prominent role in punk than they had in previous subcultures:

We wore miniskirts that were bought and cut up. We discovered fishnet tights in Anderson and McCauley/Robinson \& Cleavers and my mum's original stiletto heels which I squeezed into. Later on we wore Monkey boots with leather trousers, kilts and a motor bike studded jacket... I sometimes made my own clothes and trimmed t-shirts with fur, lace, sequins, pins and put studs on my leather jacket ${ }^{16}$.

The clothes and items mentioned in these extracts were assembled to create a dress style which contrasted sharply with 1970s mainstream fashion. Punks generally favoured black, red and metallic colours over brown, yellow and pastel colours, and tight-fitting garments and angular, harsh lines over wide, flowing clothes ${ }^{17}$. Consciously or not, they borrowed from earlier and contemporary subcultures: Dr Martens boots from the skinheads, "drainpipe" trousers and brothel creeper shoes from the teddy boys, studded leather jackets from the rockers or bikers of the 1950s, and bondage gear from alternative sexual subcultures which in the 1970s were still mostly associated with LGBT communities, such as leather or PVC fetishism communities and BDSM subcultures. In contrast to the prevailing post-hippie trend of "natural beauty", faces were pale rather than tanned, hair was chopped short and dyed in bright colours, and heavy make-up was worn by young women and occasionally by young men. Because of its oppositional aesthetic, Dick Hebdige has argued that punk was the subculture that best dramatized what had come to be called "Britain's decline". Indeed, punks appropriated the era's rhetoric of crisis and anarchy ${ }^{18}$ and thus tapped into contemporary fears (mass unemployment, violence, immigration, totalitarianism, evolving moral standards, etc.) by presenting themselves as "degenerates ${ }^{19}$ ". However, Hebdige interprets punk as a response by disaffected working-class youths to their subal-

15. Henry McDonald, Colours: from Bombs to Boom, Edinburgh, Mainstream, 2004, p. 57.

16. Maureen Lawrence, personal interview, 2016.

17. Monika Sklar, op. cit., p.80, and Dave Laing, One Chord Wonders: Power and Meaning in Punk Rock, PM Press, 2015, p. 118.

18. It was not the use of the word "anarchy" by the Sex Pistols and other bands which was shocking, but the fact that punks seemed to welcome and celebrate anarchy. Indeed, the word was used prominently in the media throughout the 1970s. To give just one example, in 1974 The Times described the UK in the following terms: "A world increasingly ruthless and increasingly irrational, a world in which the principle of order is by its nature exposed to furious attack [...]. The vanguard of anarchy is loose in the world". Dominic Sandbrook, Seasons in the Sun: the Battle for Britain, 1974-1979. London, Penguin, 2013, p. 125.

19. Dick Hebdige, Subculture: the Meaning of Style, London, Methuen, 1979, p. 85. 
tern position in late 1970 s society, while in reality many punks were from middleclass backgrounds ${ }^{20}$. In the late 1970 s it was not punks so much as skinheads who "claimed to speak for the neglected constituency of white lumpen youth ${ }^{21}$ " and who best evoked stereotypical, imagined working-class and masculine values through their tough-looking, stripped-down dress. Punk dress by contrast was closer to science fiction than to social realism ${ }^{22}$ : it drew inspiration from "low" or maligned aspects of popular culture such as pornography and the horror genre. If punk was in any way Dickensian, it was not because of its "proletarian accents" but because of its use of the grotesque ${ }^{23}$.

\section{图 Grotesque Bodies}

The grotesque is a notoriously difficult concept to define, but for the purpose of this study we will describe it as a mode of artistic and human expression that is characterised by a conflation of disparate or mutually exclusive elements whose locus is the body, but which provokes, involuntarily or not, a disturbance, deformation and distortion of order; it produces an emotional response which, initially at least, is experienced as shock, strangeness or even estrangement ${ }^{24}$. With punk it seemed that the body and its excessive physicality were both celebrated and loathed: "the uglier you were, the more true to the punk spirit you were" 25 . At any rate, it put the body on display. Young people who did not match the beauty ideals of glossy magazines wore clothes which drew attention to the body. Overtight trousers, short skirts, underwear worn as outerwear, oversized coats, pullovers and boots, short spiky hair or asymmetrical hairstyles distorted the body's proportions. Bondage trousers, heavy boots and stiletto shoes forced punks to adopt unnatural postures and gaits. Even in its more subdued manifestations,

20. London punk was composed of both working-class and (lower) middle-class elements. My fieldwork in Northern Ireland has brought me to similar conclusions about the 1970s and 1980s punk scenes in Belfast and Derry although a widescale ethnographic survey would need to be carried out to settle the question.

21. Dick Hebdige, Subculture: the Meaning of Style, op. cit., p. 63.

22. Johan Kugelberg, Jon Savage, William Gibson, Linder Sterling, and Gee Vaucher, Punk: An Aesthetic, New York, Rizzoli, 2012, p. 344-346.

23. In reality, punk was rarely naturalistic. Even in punk's more social realist manifestations - which would emerge in the 1980s in street punk, oi and anarcho-punk, but which had been foreshadowed by bands such as the Clash in London and Stiff Little Fingers or Ruefrex in Northern Ireland - society's ills were conveyed through the grotesque and the abject. As Jello Biafra, the lead singer of American punk band the Dead Kennedys, has said: "What would happen if I took the horror of Alice Cooper [...] but made it about real things that happen to people. Instead of vampires and monsters... police brutality". Jello Biafra in Punk: Attitude, dir. Don Letts, Capitol Entertainment, 2005.

24. See Stell Butter, "The Grotesque as a Comic Strategy of Subversion: Mapping the Crisis of Masculinity in Patrick McGrath's 'The Grotesque”, Orbis Litterarum 62:4, 2007, p. 338; Donald H. Ross, "The Grotesque: A Speculation", Poe Studies, June 1971, vol. IV, n 1, p. 10-11 and Istvan Csicsery-Ronay, Jr, "On the Grotesque in Science Fiction", Science Fiction Studies, Vol. 29, No. 1, 2002, p. 71-99.

25. Daniela Soave in Stephen Colegrave and Chris Sullivan, Punk, London, Bounty, 2013, p. 317. 
punk dress expressed distortion and deformity: rips, tears, zips, holes, asymmetrical lines, graffiti, studs, out-of-place objects attached to clothes or to the flesh, etc. Although there was a strong element of playfulness to punk dress ${ }^{26}-$ as in most incarnations of the grotesque - punk seems to have held particular appeal for young people in Northern Ireland who felt that they did not fit into their families, their communities or into wider society. "For anyone in the UK at that point who felt cast out because of class, sexuality, perception, gender, even choice, who felt useless, unworthy, [punk] was an attraction/repulsion machine of [...] infernal power that offered the chance of possible transcendence. In becoming a nightmare, you could find your dreams ${ }^{27}$."

\section{Abject Bodies}

Initially however, punk was not seen by the media ${ }^{28}$ or by the wider public as a source of liberation. The provocative acts of the Sex Pistols - notably their swearing on a live chat show on a local London television channel in December 1976 and their boat trip on the Thames on the day of the Jubilee of Queen Elizabeth II to promote their single "God Save the Queen" in June 1977 - were opportunities used by the media to whip up a moral panic about the emerging phenomenon. They focused on the unconventional style and behaviour of punks, exaggerating the scene's violence and its most sensationalist aspects. Although the media frenzy was short-lived, its description of the subculture in terms evoking abjection ("unpleasant", "sick and filthy", "degenerate", "revolting", "repugnant ${ }^{29 "}$ ") had long-term effects: it not only framed punk's reception by the wider society but also played a part in shaping the meaning of the phenomenon for punks themselves, as the representations circulated in the media were sometimes the only ones accessible to aspiring punks in peripheral areas. The abject, which was already a particular source of fascination for punks, thus became even more closely associated with the subculture. In common parlance, the abject refers to that which is vile and inspires disgust; etymologically, it signifies the state of being cast off and degraded. As such it is a feature of the grotesque body, with its "irrepressible growth, producing excrescences, protuberances, enormous noses and ears, pimples, tumours, genitalia ${ }^{30 "}$. And

26. The pleasure of putting together punk dress, of getting ready to go out and of shocking onlookers features prominently in the interviews I have carried out.

27. Jon Savage, England's Dreaming: Anarchy, Sex Pistols, Punk Rock, and Beyond, op. cit. 2002, p. XV.

28. At first the only music magazines to embrace punk were $N M E$, Sounds and, somewhat later, Melody Maker.

29. Dave Laing, One Chord Wonders: Powers and Meaning in Punk Rock, Oakland CA, 2015, p. 142. As mentioned above, British tabloids, which were quick to use this type of language, were sold in Northern Ireland.

30. Istvan Csicsery-Ronay, Jr, "On the Grotesque in Science Fiction”, Science Fiction Studies, Vol. 29, No. 1. 2002: 87 . 
indeed, "vomit, snot, spitting, menstrual blood, fetishism, obscenity, perversion, violence, unreason ${ }^{31}$ " were used as inspiration for the names of Northern Irish punk bands (the Outcasts, Victim, the Defects, Stalag 17, Stage B, Toxic Waste...) and album art (the sleeve of Rudi's 1978 single "Big Time" featured a zombie-like monster ${ }^{32}$ ), and was theatricalized in the performances, practices, and bodies of punks. Safety pins were pushed through earlobes or other body parts; a few punks practised self-mutilation. A much more widespread practise was "gobbing": spitting on band members during performances, a phenomenon which lasted longer in Northern Ireland than in Britain. Through these abject displays, "punk [acted] out a literally violent rejection of mainstream models of identity, as expressed through dominant ideals of bodily decorum ${ }^{33}$ ". This rejection was further emphasised by the use of fascist imagery, a practice which has been interpreted both as a quasi-Situationist attempt to demystify the sign and as a generational, adolescent act of provocation, "an anti-mums and antidads thing 34 ". Pictures and testimonies reveal that Northern Irish punks, just like their London counterparts, toyed with Nazi symbols (swastikas, surplus German army jackets, the infamous "Destroy" t-shirts, which featured a large swastika) and occult imagery (pentangles, upside-down crucifixes, Satanic inscriptions, etc. $)^{35}$. The display on punk bodies of symbols which referenced what Julia Kristeva calls the "abjection of Nazi crime" or which celebrated that which is "immoral, sinister, scheming, and shady" stemmed from punks' conscious desire to set themselves apart, to mark themselves as dejects ${ }^{36}$. For Julia Kristeva, the abject not only has the quality of being opposed to the "I", it is "something" that the "I" does not recognize as a thing 37 . It defies categorization; it disturbs order and meaning, and can thus be seen as a feature of the grotesque. Abjection is caused by an encounter with the grotesque body's individual parts - which challenge order because of their excessive or unusual features or functions - and with the grotesque body as a whole, because of the sum of its disparate or mutually exclusive parts. It is "not lack of cleanliness or health that causes abjection but what disturbs identity, system, order. What does not respect borders, positions, rules. The in-between, the ambiguous, the composite ${ }^{38}$. The display by punks of their abject, grotesque bodies had the

31. Paul Cobley, "Leave the Capitol" op. cit., p. 174.

32. Good Vibration Records, 1978.

33. Jim Ellis, Derek Jarman's Angelic Conversations, Minneapolis, U of Minnesota, 2009, p. 57.

34. Siouxsie Sioux in Jon Savage, op. cit., p. 241.

35. Henry McDonald, Colours: from Bombs to Boom, op. cit., p. 37.

36. Julia Kristeva and Leon S. Roudiez, Powers of Horror: An Essay on Abjection, New York, Columbia UP, 1982, p. 4

37. Ibid., p. 1-2.

38. Ibid., p. 4. 
unintended consequence of drawing attention to the fragility of the boundaries they inhabited; at the very least, they hinted at the possibility of transgression.

\section{圈 Monstrous Bodies}

Whether punks wanted to cause abjection or not, their grotesque bodies were perceived by others as abject. They themselves also depicted the body as grotesque in their songs. The figure of the monster being one of the most widespread embodiments of the abject and the grotesque in postwar popular culture, notably in horror and in science fiction, it is no surprise that monsters feature prominently in punk iconography, either in the form of human murderers or other-thanhuman creatures. Monsters, like the punk body, disturb boundaries:

Monsters are un-natural relative to a culture's conceptual scheme of nature. They do not fit the scheme; they violate it. Monsters are not only physically threatening; they are cognitively threatening. They are threats to common knowledge ${ }^{39}$.

The monstrous is particularly noticeable in the material of one of Northern Ireland's most popular punk rock groups, the Outcasts, from Belfast. Their song "The Princess Grew Up A Frog" ${ }^{40}$ tells the tale of a "cute little girl with golden curls", who is told by her family that she is "God's gift to the world" and is so pretty that she appears in an advertisement for children's clothes. However, this leads to her becoming arrogant, and her hubris is punished when "at thirteen she got spots/And at fourteen she had to wear a brace". The princess thus grows up a "green green, slimy green" frog but is unable to find a prince willing to "break the evil spell". The contempt of the narrator is obvious in the disparaging tone of voice adopted by Outcasts frontman Greg Cowan, who spits out the words with a mixture of glee and disgust. It is tempting to read the song as a subconscious expression of the fear of the mutating adolescent body, and notably of the female body. Conventionally, the female body is seen as metamorphic ("menstruation, pregnancy, childbirth, lactation, menopause"), which makes it an essential aspect of the grotesque ${ }^{41}$. Puberty in particular is the moment "when childhood innocence may be swapped for the mantle of monstrosity associated with abject

39. Noël Carroll in Alexis de Coning, "Sympathising with a Monster: An Exploration of the Abject 'Human Monster' in Iain Banks' The Wasp Factory”, in Elizabeth Nelson, Jillian Burcar and Hannah Priest (eds.), Creating Humanity, Discovering Monstrosity: Myths \& Metaphors of Enduring Evil, Oxford, Inter-Disciplinary Press, 2010, p. 164.

40. This song and all other Outcasts songs mentioned in this paper are from the album Self Conscious Over You, Good Vibrations Records, 1979.

41. "The association of the female body with materiality, sex, and reproduction in the female body, makes it an essential - not an accidental - aspect of the grotesque”. Miles in Istvan Csicsery-Ronay, Jr, op. cit., p. 86. 
fecundity", and here that mantle takes the shape of a frog, but, contrary to the fairy tale, it is a monster which cannot be redeemed ${ }^{42}$. Femininity is both desired and "feared and abjected" because of male castration anxieties or envy of women's reproductive power ${ }^{43}$, but especially due to the fact that the feminine is always the other against which the masculine is defined. There is an attempt to sublimate or at least to manage the monstrous-feminine in the Outcasts song "Clinical love". The song opens with the chime of a music box - a sound both evocative of childhood and a common trope in horror films ${ }^{44}$ - but is then replaced by low-pitched, midtempo palm muted guitar downstrokes which soon become the backdrop to Cowan's gloom-laden vocals: "2023 AD/Germs and illness have been eradicated/ Physical contact is outdated/Except for the selected breeding few/And we are two of the potent few". The female body - whose presence is implied, but not mentioned in the verse - is sanitised, regulated and, ultimately, repressed by a dystopian society which still needs it for reproduction: it is a fecund body with the abject ("germs", "illness") removed. However, in the chorus, physicality and sexuality reassert themselves; the repressed abject returns: "Come on be my zombie babe/ Come on be my lover too/Come on be my zombie babe/Give me love/So cold and clinical". It turns out that the potent, selected breeding few are zombies - the most abject of monsters, for they are animated corpses, creatures both living and dead. The attempt to contain sexuality, and especially the female body, has failed. As in science fiction or horror narratives, the creatures have escaped from the laboratory, which here may stand for a safe, pre-pubescent space, and they have emerged into a world where they can now mate without control and for pleasure rather than for reproductive purposes. And yet the narrator asks the "zombie babe" for a form of "cold and clinical" love, a sexual encounter devoid of the abject - which, of course, is impossible. These lyrics seem to betray a longing for the certainties or the familiarity of the pre-pubescent stage of development and a fear of female desire and of the monstrous-feminine body. The explicit expression of abjection when dealing with the ambiguous attraction-repulsion impulse found in these two songs is characteristic of punk sexual discourse. The female body, constructed as metamorphic and abject, is feared because it threatens the relationship between the sexes as well as the identity of each sex, according to Kristeva ${ }^{45}$. Because of its position of power and the fact that it defines itself in opposition to other gender identities, it is hegemonic masculinity which risks being called into question; the boundaries it uses to construct itself risk being displaced or dissolved.

42. Jane M. Ussher, Managing the Monstrous Feminine: Regulating the Reproductive Body, London, Routledge, 2006 , p. 8.

43. Ibid., p. 6.

44. Both The Innocents (1961) and Rosemary's Baby (1968) feature nursery rhymes and music box tunes.

45. Julia Kristeva and Leon S. Roudiez, Powers of Horror: An Essay on Abjection, op. cit, p. 71. 
This is illustrated in the song "Bewerewolf4" by another Belfast band, Rudi, in which a werewolf is threatened with being shot with a silver bullet. Although in contemporary popular culture the werewolf is generally depicted as a masculine monster, its lack of control over its own body and appetite, its association with the moon and its cycles, and its animality are characteristics historically used to describe and abjectify the female. What is feared is not the werewolf's animality but its ambivalence, the fact that it is both human and other-than-human and that it is not reducible to one or the other. The threat of the silver bullet being fired into the penetrable, monstrous-feminine flesh of the werewolf can then be read as an attempt to put an end to the curse of an unstable, metamorphic body and to reassert hegemonic masculinity over and against feminine and other subaltern gender identities. The monstrous-feminine body, no longer concealed, must be got rid of. In an interesting twist, the title of the song and lyrics of the chorus are themselves ambiguous: "Silver silver bullet/Beware wolf" could also be understood as "Be werewolf", as the spelling of the title suggests. The warning issued to the werewolf can thus be read or heard on another level as being a call to become the shapeshifting creature, and to embrace rather than resist the monstrous. And indeed, in several Northern Irish punk songs, the monstrous is reclaimed or celebrated. In "Clinical Love", both the narrator and the "zombie babe" are monsters; this is even clearer in songs like "Cyborgs" by the Outcasts or "We're Only Monsters" by the Co-ordinates, which we will come to later. Songs such as these reveal the fluidity of the boundaries between man and monster, male and female, living and dead, normal and abnormal.

The thematic exploration of the grotesque and the monstrous in Northern Irish punk rock songs ${ }^{47}$ did not amount to a conscious transgression of gender and sexual boundaries ${ }^{48}$, but the playful, parodic use of common fairy tale figures and tropes - no doubt inspired by their reinterpretation in contemporary horror and science fiction comics, films and television series - and in particular the repositioning of the feminine body, threatened to subvert the codes of heteronormative sexuality and of hegemonic masculinity, and pointed to the instability of boundaries in a society where they were deemed immutable.

46. Rudi, "Bewerewolf?", Spit Records, 2015, vinyl record (reissue of 1981 EP).

47. It also appears in songs like "Bondage in Belfast" by the Androids, "Rabies" and "Strange Thing by Night" by Victim, "Lizzie Borden" by Stage B, "Fringes" by the Doubt, "Barbed Wire Love" by Stiff Little Fingers, etc. 48. Although the 1970s punk subculture often acted as a safe space for women and for LGBTQ people, it was still in many ways a heteronormative culture. 


\section{Blurring the Lines}

The instability of boundaries was further signalled by the fact that punk dress cultivated an ambiguous sexual identity. The wearing of earrings and bondage gear by both sexes, the juxtaposition of short dyed hair and leatherwear or PVC clothing, and the occasional use of makeup by young men not only blurred the boundaries between male and female, they were also direct appropriations from gay and lesbian culture as well as from alternative sexual subcultures. Punk's "queerness ${ }^{49}$ " often provoked a negative reaction, especially outside cosmopolitan London, where being a punk was "an affront to an assortment of deep-rooted values: class, masculinity, "decent" behaviour, locality and "tradition" ${ }^{50 "}$. In British towns in the 1970s, where unemployment was rife, there existed a "white underclass [...] in which the men [were] the most likely of all men to adopt aggressive masculine styles and values whereby status [was] imparted to those who display[ed] loyalty and bravery in confrontation with outsiders". In Northern Ireland, challenging established boundaries was particularly transgressive because it was a highly gender- and heteronormative society, where bodies were routinely controlled ${ }^{51}$ : indeed, paramilitarism reinforced a martial view of masculinity, while the power of religious institutions - the Catholic church as well as Protestant and especially Evangelical churches - meant that even among young people, social attitudes regarding sexual mores tended to be conservative: in 1978 Northern Irish male teenagers were much more likely to frown on pre-marital sex than their English peers, for instance ${ }^{52}$. Above all it was the body and sexuality of women and LGBTQ people which were controlled: legal access to abortion was and still is heavily restricted and homosexual acts were only decriminalised in $1982^{53}$. In this context, the punks' blurring of the boundaries meant that they were sometimes the target of abuse, which could range from being called homophobic slurs to being beaten up. The punks' non-normative bodies were seen as so threatening because

According to Freud, the outlines of the body are the foundations of the bodily ego and hence the sense of the self. In punk culture, the out-

49. For a general discussion of the links between 1970s punk and queerness, see Tavia Nyong'o, "Do You Want Queer Theory (or Do You Want the Truth)? Intersections of Punk and Queer in the 1970s", Radical History Review, Volume 2008, Number 100, 2008, p. 103-119.

50. Paul Cobley, "Leave the Capitol" op. cit., p. 171.

51. The conflict led to specific forms of body control which could potentially affect anyone: from official forms of policing which consisted in searching and patting people down at checkpoints or in front of shops to the brutal forms of social control exerted by paramilitary groups (kneecapping and punishment beatings), as well as the British army's aggressive "five techniques" of interrogation.

52. Ed Cairns, Caught in Crossfire: Children and the Northern Ireland Conflict, Belfast, Appletree, 1987, p. 72-76.

53. Even then, the age of consent was 21. 
lines of the body are no longer stable. The violence and anarchy embraced by the punk movement were terrifying to the mainstream in part because they were ultimately directed at the dominant conception of selfhood. Punk threatened not the dissolution of society but, more radically, the dissolution of the self ${ }^{5}$.

However, I would argue that punk could indeed be taken to threaten the dissolution of society, precisely because it threatened the dissolution of the self. In the context of the Northern Ireland conflict, the use of the grotesque in punk dress and songs did not only challenge preconceived notions about the gendered and heteronormative self; it also threatened ethno-religious identification. While walls, murals, flags, painted street kerbs, graffiti were used in urban spaces as markers of identity which signalled the territorial and cultural boundaries of nationalist-republican and unionist-loyalist communities, signs of difference were also located in the body itself. The desire to police the boundaries of the community and to seek ways of identifying the other was seen as a form of self-preservation. The fear of the other was increased by the very real danger posed by undercover soldiers, paramilitaries or sectarian killers like the Shankill Butchers ${ }^{55}$. Thus people in Northern Ireland, especially those living close to "interface" areas, quickly became used to the practice of scanning strangers for signs of otherness. In a discussion of Edward Said's concept of Orientalism - which can be applied to analyse the process of othering subaltern groups living in colonial or post-colonial contexts within Western societies - Ghaforian, Moosavinia, and Niazi assert that "othering codifies and fixes the self as the true human and the other as other than human ${ }^{56}$ ". Thus signs which may have seemed anodyne elsewhere were invested in Northern Ireland with meaning: the style of clothes, the haircut, vocabulary, accents, pronunciation of a consonant, even the features of the body. Irish people had been described as racially and ethnically other as far back as the Anglo-Norman conquest $^{57}$; in Britain and in the United States Irish Catholics in particular were not considered fully white until the late nineteenth century. During the Troubles, since skin colour could not be used as a sign of difference, other physical markers were constructed. Thus Catholics were described by Protestants as being skinny,

54. Jim Ellis, Derek Jarman's Angelic Conversations, op. cit., p. 57.

55. The "Shankill Butchers" were an Ulster Volunteer Force (UVF) gang which from 1975 to 1977 roamed the streets of Belfast and carried out a series of horrific murders. They are believed to have killed at least 19 people, almost all of whom were Catholic. "Violence - Significant Violent Incidents During the Conflict", CAIN Web service.

56. S. R. Moosavinia, N. Niazi and Ahmad Ghaforian, "Edward Said's Orientalism and the Study of the Self and the Other in Orwell's Burmese Days", Studies in Literature and Language, Vol. 2, No. 1, 2011, p. 105.

57. Gerald of Wales's Topography of Ireland (1188) and Expugnatio Hibernica (1189), which were written to justify the Anglo-Norman conquest of Ireland, described the Irish as barbarians and were later relied on by English writers. S.J. Connolly, The Oxford Companion to Irish History, Oxford, Oxford University Press, 2007, p. 230. 
having dark hair and eyes, and always looking hungry - bringing back to life the haunting memory of victims of the Great Famine. Protestants were themselves perceived by Catholics as being blonde, having big bones and large features, and rarely smiling or talking to strangers ${ }^{58}$. Both communities described the other as having their eyes set close together, and in some working class neighbourhoods, children were even taught that Catholics had horns under their hair ${ }^{59}$. In Northern Ireland the bodies of members of the other side were thus described in terms which evoked the grotesque and the monstrous. But while each community was busy projecting monstrous characteristics onto their rivals and mutually accusing each other of abject behaviour, punks, as we have seen, openly submitted their own bodies to monstrous mutations and revelled in the grotesque. Almost simultaneously to punks' bodily experimentations there emerged a new form of political protest, which similarly put the grotesque and abject body on display: the 1978-1980 "dirty protest" and the 1980-1981 hunger strikes by republican prisoners. If the "emaciated, gaunt, sometimes twisted bodies of the hunger strikers challenged the fantasy of the macho warrior by depicting the consequences of war on the male body ${ }^{60}$, , the grotesque bodies of punks evoked something entirely different. Redolent of Catholic crucifixes, the "fragile, weak, wounded and frail" bodies of the republican protestors had a purpose: they saw themselves as offering up their bodies as a "Christ-like sacrifice" which would redeem the nationalist community. This near-religious structuration of abjection purifies and sublimates the abject: the bodies of the hunger strikers become sacred, consecrated. Not so for punks, whose abject, monstrous bodies signalled their participation in a subculture which in terms of the Troubles was - initially and superficially at least apolitical, and which, rather than reinvigorating one of the two communities, challenged the boundaries of both. Punks seemed to lie outside the frames of interpretation of both communities: they could be made to fit neither the nationalist-republican narrative of self-sacrifice, submission to the community and devotion to the struggle against British rule nor the unionist-loyalist narrative of loyalty to the British Crown and defence of a Protestant "Ulster". The refusal to play by the rules of Northern Irish society is expressed in the Outcasts song "You're a disease", which, although it appears to be a break-up song, can be inter-

58. See Frank Burton, "Ideological Social Relations in Northern Ireland", The British Journal of Sociology, Vol. 30, No. 1, Wiley, 1979, p. 61-80; Ashley Merryman, "Divided Loyalties", National Catholic Reporter, 8 April 2005; Dervla Murphy, A Place Apart: Northern Ireland in the 1970s, London, Eland, 2014, p. 73.

59. One ex-punk from the Shankill, a staunchly loyalist area, remembers how children from the neighbourhood had a close look at his friend from the nationalist Falls Road to see whether his eyes were set close together and checked his hair for horns, as they had been taught that Catholics displayed such unusual features (Lee Martin, personal interview, 2014).

60. Edwin Coomasaru, "Emaciating machismo: masculinity, murals and memorialising hunger strikes", The Irish Times, 5 May 2016. 
preted as dealing with the abjection of sectarianism and its consequences: "You're a disease/I don't want to catch." The implications of participation in an "inbetween", "ambiguous", "composite" subculture become clearer in the Outcasts' song "Cyborg": "We are the new generation/We are the new scientific creation/ Half-machine, half-boy and girl/Sent to overrun the rule of nature." Given the primary context of reception of this song - the largely cross-community Northern Irish punk subculture - the "we" can be taken to represent both Catholic and Protestant young people. Indeed, a cyborg is a composite being, an organic creature whose functions are restored or enhanced through artificial means. "Cyborgs", argues Csicsery-Ronay Jr, "are by definition not linked to traditions, to families and clans, and to traditional nations". In science fiction, they are an "attempt to imagine what personal identity might be like after the full deconstruction of traditional communal loyalties ${ }^{61}$ ". The Outcasts' hymn to hybridity thus contains a warning: "You are the old days, we are the new ways/You are the old ways, we are the new days." It is interesting in this regard to note that the word monstrum - which in Latin means "portent" - derives from the etymon monere: "to warn". Punks were monsters because they threatened to reveal the arbitrary nature of the Us-Them binary and to disrupt the process of othering: they were "transgressors of social norms and violators of accepted cultural codes ${ }^{62}$ "; they "threatened to overturn cherished ideals, their symbols and institutions $s^{63}$ ". Punks could be seen as abject not only because of their grotesque dress style but because they raised the fear of "the shame of compromise, of being in the middle of treachery ${ }^{64}$ ". As a result, they were often picked on by peers within their respective communities and beaten up - just as they were for their perceived queerness and on a few occasions they were threatened by both republican and loyalist paramilitaries. The song "We're Only Monsters" by the Co-Ordinates was written as a response to the attitudes of peers, authority and the media towards punks in Northern Ireland: "They're trying to tell us/We're only monsters/Anti-establishmentarianism/We're only monsters/The youth of today should be thrown in prison/We don't care what they say/Give us music any old way ${ }^{65}$." Despite the perceived transgressiveness of punk, what attracted young people to it was the exciting music and the promise of "unbridled leisure, pleasure and carefree fun ${ }^{66 "}$. Because of this, young Catholics and Protestants from both working-class and middle-class

61. Istvan Csicsery-Ronay, Jr, op. cit., p. 77. Csicsery-Ronay Jr argues that cyborgs are seen as embodiments of the "negative" grotesque until the mid-80s, after which representations of cyborgs become much more positive.

62. Alexis de Coning, The Wasp Factory, op. cit., p. 165.

63. Paul Cobley, "Leave the Capitol", op. cit., p. 175.

64. Julia Kristeva and Leon S. Roudiez, Powers of Horror: An Essay on Abjection, op. cit., p. 2.

65. Shellshock Rockers, Spit Records, 2011.

66. Bill Osgerby, "The teenage aesthetic and genealogies of American punk", in Roger Sabin (ed.) Punk rock, so what? the cultural legacy of punk, London, Routledge, 2009, p. 156. 
backgrounds, and to a certain extent both young men and young women, continued to meet up in shared spaces across Northern Ireland. Not all punks were non-sectarian, and the fragile unity of the 1970s punk subculture was sometimes put to the test, but all in all punk levelled the field: if young Catholics were monsters, if young Protestants were monsters too, then they had more in common than they had previously thought. The spaces in which the grotesque punk bodies assembled were thus the site of carnivalesque interactions in the Bakthinian sense: they allowed eccentric behaviour of a sacrilegious nature, carnivalistic misalliances, and the free and familiar interaction between people who were normally separated. The world was thus turned upside down and normal rules were suspended. But like the feast of fools, like Foucault's heterotopias, these interactions were limited in time and space. In the early 1980s, changing trends in music, the break-up of many of the original bands, the rise of sectarian skinheads and the climate of increased sectarianism following the republican hunger strikes and the subsequent backlash all contributed to the demise of the first wave of Northern Ireland punk. Nevertheless, for a short while at least, punk in Northern Ireland acted as a hybrid space - as theorised by Bhabha - insofar as it provided a "liminal space at the boundaries of two cultures", a space from which power relations were not magically elided but which enabled them to be negotiated in novel ways and, ultimately, challenged ${ }^{67}$. By using the grotesque and the monstrous not as a process of othering and abjectifying people from rival communities, but rather as a tool for aesthetic, lyrical and stylistic expression, punks unwittingly launched themselves into an exploration and a questioning of some of the boundaries which were fiercely enforced in Northern Irish society. What Jim Ellis has said about LGBTQ people and "unconventional" women can thus be applied to the young Northern Irish punks of the 1970s: for them, for a while at least, punk marked "the triumph of the freakish outsider ${ }^{68 "}$.

67. F.C. McGrath, "Settler nationalism: Ulster unionism and postcolonial theory", Irish Studies Review, Vol. 20, No. 4, November 2012, p. 467.

68. Jim Ellis, Derek Jarman's Angelic Conversations, op. cit., p. 58. 